\title{
PEMBERDAYAAN MASYARAKAT MELALUI PELATIHAN MENYULAM \\ PADA IBU-IBU DI DESA PABUARAN \\ KECAMATAN SUKAMAKMUR KABUPATEN BOGOR
}

\author{
Drs Sri Koeswantono W \\ Fakultas Ilmu Pendidikan Universitas Negeri Jakarta \\ Sri_kuswantono@unj.ac.id
}

\begin{abstract}
ABSTRAK
Desa Pabuaran yang terdapat di Kecamatan Sukamakmur, Kabupaten Bogor adalah salah satu desa yang masyarakatnya memiliki pendapatan yang masih rendah atau masyoritas masyarakatnya masih dalam kondisi miskin. Salah satu yang dilakukan untuk mengatasi masalah masyarakat tersebut yaitu melalui kegiatan pemberdayaan masyarakat. Adapunkegiatan pemberdayaan yang dilakukan yaitu melalui pelatihan menyulam yang sesuai dengan kebutuhan masrakat tersebut.Pendekatan pembelajaran yang digunakan dalam pelatihan ini yaitu pendekatan andragogi dengan metode ceramah, diskusi, dan praktek. Pelaksanaan kegiatan pelatihan menyulam di Desa Pabuaran, Kecamatan Sukamakmur, Kabupaten Bogor ini yaitu dilaksanakan pada 21 September 2014. Hasil dari kegiatan pelatihan ini yaitu meningkatnya kemampuan ibu-ibu di Desa Pabuaran dalam membuat sulaman yang dapat dimanfaatkan menjadi sumber mata pencaharian.
\end{abstract}

\section{Kata Kunci: Pemberdayaan, Pelatihan, Andragog}

\section{PENDAHULUAN}

Kemiskinan merupakan masalah dalam pembangunan yang bersifat multidimensi. Kemiskinan ditandai oleh keterbelakangan dan pengangguran yang selanjutnya meningkat menjadi pemicu ketimpangan pendapatan dan kesenjangan antar golongan penduduk. Kesenjangan dan pelebaran jurang kaya miskin tidak mungkin untuk terus dibiarkan karena akan menimbulkan berbagai persoalan baik persoalan sosial maupun politik di masa yang akan datang.

Banyak sekali faktor penyebab dari masalah kemiskinan yang terjadi pada masyarakat, diantaranya yaitu jumlah pengangguran yang tinggi diakibatkan ketersediaan lapangan pekerjaan yang terbatas, tingkat pendidikan masyarakat yang masih sangat rendah, dan masyarakat yang tidak memiliki life skill guna menghasilkan karya yang mampu di jadikan sebuah usaha. Walaupun masyarakat memiliki tingkat pendidikan yang rendah dan juga lapangan pekerjaan yang sedikit, apabila masayrakat memiliki life skill, maka masyarakat itu mampu menciptakan usaha atau lapangan pekerjaan untuk dirinya dan orang lain.

Salah satu desa yang masyarakatnya memiliki pendapatan yang masih rendah atau masyoritas masyarakatnya masih dalam kondisi miskin yaitu Desa Pabuaran yang terdapat di Kecamatan Sukamakmur, Kabupaten Bogor. Desa Pabuaran terdiri dari tiga Dusun dengan Rukun Warga (RW) 8 dan 28 Rukun Tetangga (RT) dengan jumlah penduduk 11. 077 Jiwa dengan jumlah KK sebnyak $2560 \mathrm{KK}$.

Tingkat pendidikan masyarakat Desa Pabuaran masih tergolong sangat rendah dengan jumlah lulusan SD/ MI sebanyak 6.481 orang, SMP sebanyak 250 orang, SMA sebanyak 150 orang, D3 sebanyak 4 orang, S1 sebanyak 2 orang, dan S2/S3 sebanyak 1 orang. Adapun pekerjaan masyarakat Desa Sukamakmur pada umumnya yaitu bekerja sebagai petani dengan jumlah 4570 orang.

Tingkat pendidikan yang masih rendah dan juga pekerjaan utama sebagai petani, mengakibatkan tingkat pendapatan masyarakat di Desa Pabuaran masih di bawah rata-rata. 
Sehingga tingkat kemiskinan di desa ini masih sangat tinggi. Diperlukan upaya-upaya untuk mengatasi masalah kemiskinan tersebut meskpun tingkat pendidikan masayrakat masih rendah.

Salah satu yang dilakukan untuk mengatasi masalah masyarakat tersebut yaitu melalui kegiatan pemberdayaan masyarakat. Pemberdayaan masyarakat adalah upaya untuk meningkatkan harkat dan martabat lapisan masyarakat kita yang dalam kondisi sekarang tidak mampu untuk melepaskan diri dari perangkap kemiskinan dan keterbelakangan. Dengan kata lain memberdayakan adalah memampukan dan memandirikan masyarakat.

Adapun kegiatan yang dilakukan oleh tim P2M ini dalam meningkatkan keberdayaan masyarakat khususnya pada ibu-ibu di Desa Pabuaran yaitu dengan memberikan kegiatan pelatihan. pelatihan yaitu memberikan, memperbaiki dan juga menambah kemampuan seseorang yang semata mata bertujuan untuk meningkatkan keahlian, sikap disiplin kerja, memperbaiki kekurangan dalam tingkat kompetensi yang ingin dicapai. Adapun kegiatan pelatihan yang diberikan kepada masyarakat Desa Pabuaran berupa pelatihan menyulam. Adanya kegiatan pelatihan menyulam ini diharapkan masyarakat mampu membuat sulaman yang menarik dan berkualitas sehingga dapat dijual kepada masyarakat luas.

\section{KAJIAN TEORI}

\section{A. Pelatihan}

Pelatihan menurut (1993) adalah suatu bagian pendidikan yang menyangkut proses belajar untuk memperoleh dan meningkatkan keterampilan diluar sistem pendidikan yang berlaku, dalam waktu yang relatif singkat dan dengan metode yang lebih mengutamakan praktek dari pada teori.

Kamus istilah manajemen yang ditulis oleh Soebagio (2002) mengartikan bahwa pelatihan adalah bimbingan yang diberikan oleh instruktur untuk meningkatkan keterampilan dan pengetahuan melalui penyelesaian dan tugas latihan.

Dalam buku Latihan dan Pengembangan Sumber Daya Manusia, Moekijat (1990) menyebutkan beberapa tujuan pelatihan sebagai berikut:

a. Membantu mengembangkan ketrampilan para peserta, agar mereka nantinya dapat bekerja lebih efektif dan efisien nantinya.

b. Membantu mengembangkan wawasan pengetahuan para peserta, agar mereka dapat bekerja lebih rasional dilapangan kerja yang akan mereka masuki nantinya.

c. Serta mampu mengembangkan sikap para peserta, agar mereka dapat menciptakan kerjasama yang lebih baik dengan sesama.

Chambers (1995) berpendapat bahwa pemberdayaan masyarakat adalah sebuah konsep pembangunan ekonomi yang merangkum nilai-nilai sosial. Konsep ini mencerminkan paradigma baru pembangunan, yakni yang bersifat "people centred, participatory, empowering, and sustainable".

\section{B. Pemberdayaan}

Pandangan tentang pemberdayaan masyarakat menururt Ife (1996: 59), antara lain sebagai berikut :

a. Struktural, pemberdayaan merupakan upaya pembebasan, transformasi struktural secara fundamental, dan eliminasi struktural atau sistem yang operesif.

b. Pluralis, pemberdayaan sebagai upaya meningkatkan daya sesorang atau sekelompok orang untuk dapat bersaing dengan kelompok lain dalam suatu 'rule of the game' tertentu.

c. Elitis, pemberdayaan sebagai upaya mempengaruhi elit, membentuk aliniasi dengan elit-elit tersebut, serta berusaha melakukan perubahan terhadap praktekpraktek dan struktur yang elitis. 
d. Post-Strukturalis, pemberdayaan merupakan upaya mengubah diskursus serta menghargai subyektivitas dalam pemahaman realitas sosial.

Tujuan yang ingin dicapai dari pemberdayaan masyarakat menurut Sulistiyani (2004) adalah untuk membentuk individu dan masyarakat menjadi mandiri. Kemandirian tersebut meliputi kemandirian berfikir, bertindak, dan mengendalikan apa yang mereka lakukan tersebut. Untuk mencapai kemandirian masyarakat diperlukan sebuah proses. Melalui proses belajar maka secara bertahap masyarakat akan memperoleh kemampuan atau daya dari waktu ke waktu.

Berikut tujuan pemberdayaan menurut Tjokowinoto dalam Christie S (2005: 16) yang dirumuskan dalam 3 (tiga) bidang yaitu ekonomi, politik, dan sosial budaya ; "Kegiatan pemberdayaan harus dilaksanakan secara menyeluruh mencakup segala aspek kehidupan masyarakat untuk membebaskan kelompok masyarakat dari dominasi kekuasan yang meliputi bidang ekonomi, politik, dan sosial budaya.

\section{METODE PELAKSANAAN}

Pendekatan pembelajaran yang digunakan dalam pelatihan ini yaitu pendekatan andragogi dimana peserta peltihan tidak hanya sebagai objek namun sebagai subjek pelatihan. Metode yang dipilih adalah metode ceramah, diskusi, dan praktek. Dengan digunakannya ketiga metode pembelajaran tersebut diharapkan proses pelatihan akan maksimal dan hasil dari pelatihan itu sendiri juga akan maksimal yaitu meningkatnya keberdayaan ibu-ibu dalam menyulam atau membuat sulaman.

\section{HASIL DAN PEMBAHASAN}

Pelaksanaan kegiatan pelatihan menyulam di Desa Pabuaran, Kecamatan Sukamakmur, Kabupaten Bogor ini yaitu dilaksanakan pada 21 September 2014.
Pelaksanaan dari kegiatan ini juga di bantu oleh beberapa mahasiswa Jurusan Pendidikan Luar Sekolah Universitas Negeri Jakarta yang berkoordinasi dengan Aparat Desa Paburan dan Penilik Pendidikan Luar Sekolah Kecamatan Sukamakmur.

Pada proses pelaksanaan kegiatan pelatihan menyulam, pertama kegiatan dimulai dengan perkenalan tim pengabdian masyarakat yang di ketuai oleh Drs. Sri Koeswantono, W, M.Si, dan juga fasilitator yang akan menyampaikan materi pelatihan. Selanjutnya tim pelaksana kegiatan memberika ice breaking yang bertujuan mempererat dan memfokuskan pikiran peserta sebelum mengikuti kegiatan pelatihan.

Kedua, fasilitator menjelaskan materi kepada peserta pelatihan, setelah menjelaskan secara teoritik, kemudian fasilitator mendemons-trasikan kepada peserta pelatihan bagaimana cara atau teknik menyulam. Setelah mendengarkan dan melihat demonstrasi dari fasilitator bagaimana menyulam, kemudian peserta pelatihan mempraktekkan sendiri menyulam dengan bahan-bahan atau alat-alat yang sudah disiapkan oleh tim pelaksana.

Ketiga atau pada akhir kegiatan dari pelatihan ini, peserta diberikan kesempatan untuk memberikan pertanyaan kepada fasilitator yang telah menjelaskan materi. Kesempatan untuk bertanya ini, tidak disiasiakan oleh para peserta, banyak sekali para peserta bertanya kepada fasilitator yang telah menyampaikan materi. Banyaknya pertanyaan yang disampaikan oleh para peserta dikarenakan antusiasnya peserta pelatihan dalam mengikuti kegiatan ini. Kegiatan tanya jawab ini juga dijadikan bahan evaluasi dari hasil kegiatan pelatihan yang telah dilaksanakan.

Setelah selesainya proses tanya jawab, kemudian panitia acara menutup kegiatan dari pelatihan ini. Sebelum kegiatan penutup dilakukan, tim pelaksana, fasilitator, peserta pelatihan, dan aparat desa, bersepakat bahwa masalah rendahnya penghasilan masyarakat harus diatasi secara komprehensif. Aparat desa 
harus memberikan berbagai macam program pemberdayaan bagi masyarakat melalui berbagai macam kegiatan pelatihan yang memang mampu meningkatkan keberdayaanmasyarakat-nya. Ketika masyarakat tersebut sudah mencapai pada satu titik dimana mereka berdaya, maka masyarakat dengan sendirinya mampu meningkatkan taraf hidupnya dengan menciptakan berbagai macam usaha kreatif, salah satunya penjualan hasil sulaman.

\section{KESIMPULAN DAN SARAN}

\section{Kesimpulan}

Kesimpulan yang dapat diambil dari pelaksanaan kegiatan pelatihan di Desa Pabuaran, Kecamatan Sukamakmur, Kabupaten Bogor yaitu:

1. Rendahnya tingkat pendapatan masyarakat di Desa Pabuaran yang disebabkan oleh rendahnya life skill yang dimiliki dalam memanfaatkan segala potensi sumber daya alam yang tersedia.

2. Kurangnya inisiatif dari aparat desa dalam memberikan alternatif pemecahan masalah terkait rendahnya tingkatan pendapatan masyarakat yang terdapat di wilayahnya.

3. Tim pengabdian masyarakat, mahasiswa PPL Jursan PLS, dan juga aparat desa setempat berkolaborasi dalam mengadakan kegiatan pelatihan menyulam guna meningkatka life skill yang dmiliki oleh masyarakat.

4. Terdapat peningkatan kemampuan atau life skill masyarakat dalam menyulam.

\section{Saran}

Berdasarkan kesimpulan maka disarankan kepada beberapa pihak diantaranya adalah:
1. Aparat Desa Pabuaran harus terus membantu masyarakat dalam mengatasi masalah rendahnya tingkat ekonomi masyarakatnya dengan menyediakan berbagai macam program pemberdayaan, salah satunya pelatihan menyulam yang telah diselenggarakan.

2. Masyarakat Desa Pabuaran harus secara aktif meningkatkan kapasitas diri dengan mengikuti berbagai macam program pemberdayaan. Sehingga berbagai manfaat akan dirasakan oleh masyarakat sendiri apabila secara konsisten aktif dalam mengikuti program-program pemberdayaan.

\section{DAFTAR PUSTAKA}

[1] A. A. Anwar Prabu Mangkunegara. 2006. Evaluasi Kinerja Sumber Daya Manusia. Jakarta: Refika Aditama.

[2] Arif, Zainudin. 1986. Materi Pokok pengembangan Program Latihan, Modul 6-9. Jakarta: Karunika Universitas terbuka.

[3] Atmodiwiryo, Soebagio. 2002. Manajemen Pelatihan. Jakarta: Ardadizya jaya.

[4] Departemen Pendidikan Nasional Dirjen PLSP. 2002. Pengelola Program PLS Berbasis PKBM, Jawa barat : Balai Pengembangan Kegiatan Belajar.

[5] Direktorat Pendidikan Masyarakat. 2010. Model-Model Pemberdayaan Masyarakat Desa Di Provinsi Jawa Tengah. Jakarta: Direktorat PNFI.

[6] Djojonegoro, Wardiman. 1999. Pengembangan Sumberdaya Manusia Melalui Sekolah Menengah Kejuruan. Jakarta: Balai Pustaka.

[7] Gomes, Faustino Cardoso. 1995. Manajemen Sumber Daya Manusia. Yogyakarta: Andi Offset.

[8] Hadari, Nawawi. 1997. Managemen Sumber Daya Manusia : Untuk bisnis yang kooperatif. Yogyakarta: Gajah Mada University Press. 
[9] Hasibuan. S.P. Malayu. 2001. Management Sumber Daya Manusia, Jakarta : Bumi Aksara.

[10] Masykur wiratmo, 1996. Pengantar Kewiraswastaan, Yogyakarta : BPFE.

[11] Moekijat. 1990. Latihan dan Pengembangan Sumber Daya Manusia.

[11] Moekijat. 1993. Evaluasi Pelatihan dalam rangka Peningkatan Produktifitas. Bandung: Mandar Maju.

[12] Usman, Sunyoto. 2008. Pembangunan dan Pemberdayaan Masyarakat. Yogyakarta: Pustaka Pelajar 